JST 8 (2) (2019)
JURNAL SENI TARI
Terakreditasi SINTA 5

\title{
Makna Simbolik Pertunjukan Tari Topeng Klana Cirebon Gaya Palimanan
}

\author{
Tio Martino, Muhammad Jazuli ${ }^{2}$ \\ Jurusan Pendidikan Sendratasik, Fakultas Bahasa dan Seni, Universitas Negeri Semarang
}

\begin{abstract}
Info Artikel
Abstrak

Sejarah Artikel

Diterima :

30 Juli 2019

Disetujui :

10 November 2019

Dipublikasikan :

27 November 2019

Keywords:

Symbolical, meaning,

Cirebon Klana Mask

Dance

Tujuan penelitian ini adalah untuk mendeskripsikan makna simbolik pertunjukan Tari Topeng Klana Cirebon. Metode yang digunakan adalah metode penelitian kualitatif dengan pendekatan semiotika. Data diperoleh melalui observasi, wawancara dan dokumentasi yang diabsahkan dengan triangulasi, kemudian dianalisis menggunakan tahap pengumpulan data, reduksi data, penyajian data dan penarikan simpulan. Hasil penelitian menunjukan makna Tari Topeng Klana terdapat pada elemen penari, gerak representatif, gendhing gonjing, busana, properti (ules, kedok, gantungan), sesaji dan lakon. Pemaknaan berasal dari masyarakat atau penonton dan seniman setempat. Penonton menginterpretasi Tari Topeng Klana Cirebon sebagai konotasi angkara murka dan wujud amarah. Seniman memaknai Tari Topeng Klana menjadi tiga interpretasi, yaitu 1) Manusia yang berada pada puncak kematangan fisik, psikis, dan pola pikir. 2) Semangat mencapai tujuan hidup dengan memegang teguh pedoman agar jauh dari ketersesatan. 3) Manusia dalam mencapai dan menetapkan suatu tujuan manusia selalu bertindak dengan penuh pertimbangan. Interpretasi masyarakat yang bertentangan dengan seniman setidaknya dipengaruhi oleh empat faktor, yaitu 1) ketidaktahuan masyarakat, 2) penghayatan yang kurang mendalam, 3) feferensi masyarakat dalam menginterpretasi berdasarkan pengetahuan yang populer di lingkungannya, serta 4) faktor seniman.
\end{abstract}

\begin{abstract}
The purpose of this study was to describe the symbolic meaning of the performance of Cirebon Klana Mask Dance. The method used is a qualitative research method with a semiotic approach. Data were obtained through observation, interviews and documentation that were validated by triangulation, then analyzed using the stages of data collection, data reduction, data presentation and conclusion drawing. The results showed that the meaning of Klana Mask Dance was on the elements of the dancers, the representative movements, gendhing gonjing, costumes, property (ules, mask, gantungan) offerings and story. Meaning comes from the community or the audience and from the local artist. The audience interpreted Cirebon Klana Mask Dance to be more of a connotation of anger. Artists interpret Klana Mask Dance into three interpretations, namely 1) Humans who are at the peak of physical, psychological, and mindset maturity. 2) The spirit of achieving the goals of life by upholding the guidelines so that they are far from being lost. 3) Humans in achieving and setting a goal humans always act with consideration. Community interpretations that conflict with artists are at least influenced by four factors, namely 1) ignorance of the community, 2) Less profound appreciation, 3) Community references in interpreting based on popular knowledge in their environment, and 4) artist factors.
\end{abstract}

(C) 2019 Universitas Negeri Semarang
Alamat korespondensi:
Gedung B2 Lantai 1 FBS UNNES
Kampus Sekaran, Gunungpati, Semarang, 50229
Email : 1. tiomartino97@gmail.com
2.muhjaz61@gmail.com ISSN 2503-2585 


\section{PENDAHULUAN}

Tari Topeng Cirebon merupakan salah satu khasanah kebudayaan terbesar masyarakat Cirebon. Pemberian nama Tari Topeng karena dalam pertunjukannya ada adegan penari menggunakan penutup wajah atau masyarakat Cirebon sendiri sering menyebutnya dengan sebutan kedok. Istilah topeng bagi masyarakat Cirebon merupakan gabungan dari dua kata yang tidak sama kemudian dipotong suku kata akhirnya kemudian digabungkan atau disebut 'Tembung Camboran Tugel'. Dua kata yang merupakan 'Tembung Camboran Tugel' yaitu 'ketop-ketop' yang berarti berkilauan dan 'gepeng' yang berarti pipih (Dyah 2007: 226).

Bentuk pertunjukan Topeng Cirebon saat ini merupakan tarian lepas dari beberapa tokoh utama dalam cerita panji. Susunan tokohtokoh topeng yang dipertunjukan adalah Panji, Pamindo, Rumyang, Tumenggung dan Klana. Berdasarkan lima karakter topeng yang ada, Tari Topeng Cirebon yang mendapat banyak perhatian dan paling mendapat antusias penonton adalah Tari Topeng Klana. Begitu pun dengan para murid beberapa sanggar lebih tertarik untuk mempelajari tari Topeng Klana dibandingkan dengan karakter Tari Topeng Cirebon yang lainnya. Tari Topeng Klana juga kerap kali dipilih sebagai pengisi acara hiburan beberapa acara seperti peresmian gedung, penyambutan tamu kehormatan, dan beberapa acara lainnya baik acara pemerintahan maupun acara lembaga tertentu. Antusias yang lebih terhadap Tari Topeng Klana didasarkan pada gerak Tari Topeng Klana yang enerjik dan bersemangat.

Gerak enerjik dan bersemangat disertai dengan pemakaian topeng yang berwarna merah dengan ekspresi yang meyeramkan membuat Tari Topeng Klana mengundang banyak pemaknaan dari berbagai persprektif. Masyarakat sebagai penonton memaknai Tari Topeng Klana sebagai manusia yang penuh dengan angkara murka dan tidak dapat mengendalikan hawa nafsu (wawancara dengan Waji (salah satu penonton Tari Topeng Klana) tanggal 11 Mei 2019, pukul 15.25 WIB). Seniman memberi makna Tari Topeng Klana sebagai manusia yang berada dalam puncak kematangan fisik dan psikis sehingga dalam mencapai tujuan manusia selalu berpegang teguh pada pedoman.

Pemaknaan terhadap suatu karya tari bersifat bebas, seperti yang diungkapkan oleh Hadi bahwa simbol dalam tari merupakan significant simbol yang pemaknaannya mengundang banyak reaksi yang berbeda atau tidak harus sama, begitu pun dengan Tari Topeng Klana Cirebon yang dimaknai dengan bebas oleh masyarakat. Namun, Hadi melanjutkan bahwa perlu memperhatikan pandangan-pandangan seniman guna tajamnya suatu analisis makna dalam suatu tari.

Penelitian terkait makna simbolik terhadap Tari Topeng Klana Cirebon belum peneliti jumpai. Artikel dalam Jurnal Visual Art dan Desain yang ditulis oleh Ayoeningsih Dyah pada tahun 2007 dengan judul "Makna Simbolis pada Unsur Visual Kostum Tari Topeng Babakan Cirebon Keni Arja di Desa Slangit". Artikel Dyah mendeskripsikan secara mendalam mengenai simbol-simbol yang tertuang secara visual dalam kostum Tari Topeng sebanyak lima wanda berdasarkan hasil rekonstruksi dari relief Borobudur, naskah Damar Wulan pada abad 18, catatan Thomas Stamford Raffles pada tahun 1811-1816, Kerajaan Kalimantan pada 1879, catatan Piegeaud pada tahun 1938, dan kostum Tari Topeng yang dimiliki Keni Arja pada Tahun 2006. Dyah menyimpulkan bahwa kostum yang digunakan Keni Arja yang masih terlihat adanya unsur-unsur dari kostum yang lama adalah adalah sobrah, topeng, kalung, ikat pinggang, selendang, dan kain dodot, sehingga proses pemaknaan yang dilakukan Dyah hanya melakukan pemaknaan kostum Tari Topeng Cirebon terhadap sobrah, topeng, dan kain dodot yang dipandang sebagai unsur utama dalam kegiatan pertunjukan topeng. Persamaan dengan penelitian ini yakni terletak pada kajian mengenai makna simbolis tetapi pada artikel Dyah hanya berfokus pada pendeskripsian makna pada simbol yang tertuang secara visual di dalam kostum Tari Topeng Cirebon sebanyak lima wanda. Berbeda dengan penelitian makna ini yang membahas makna simbolik yang terdapat pada seluruh elemen pertunjukan Tari Topeng Klana yang meliputi penari, gerak, iringan, kostum, properti, sesajen, hingga lakon yang dibawakan. Artikel Dyah mampu memberikan gambaran makna simbolik pada kostum yang digunakan dalam Tari Topeng Cirebon.

Tari Topeng Klana memiliki gerak enerjik dan bersemangat menimbulkan dua interpretasi dari masyarakat dan seniman jelas berbeda dan bersifat kontradiktif. Bahkan keberadaan makna yang merupakan pendapat seniman keberadaannya tidak nampak. 
Ketidaknampakan makna yang didasarkan pada pendapat seniman menjadi salah satu latar belakang diadakannya penelitian ini guna mengungkap makna-makna yang dikandung oleh Tari Topeng Klana Cirebon gaya Palimanan baik dari sudut penonton maupun seniman. Sehingga masalah dalam penelitian ini dapat dirumuskan apa makna simbolik pertunjukan Tari Topeng Klana Cirebon gaya Palimanan?

Penelitian ini menggunakan teori simbol yang dikemukakan oleh Susanne K. Langer yang membagi simbol menjadi dua macam (Sachari 2002: 18-19) yaitu: 1) Discursive symbol atau simbol diskursif yang menyiratkan suatu struktur yang dibangun oleh berbagai unsur teratur yang dapat dipahami maknanya. 2) Presentational symbol atau simbol presentasional merupakan suatu konstruksi yang tidak dapat diuraikan ke dalam unsur-unsur. Namun, suatu kesatuan bulat dan utuh serta tidak dapat diuraikan lagi ke bagian lain yang lebih kecil. Demikian pula Sudiarja dalam Suherman (2016:8) menyatakan bahwa simbol presentasional merupakan simbol yang berdiri sendiri secara utuh.

Pemaknaan simbol kemudian dianalisis melalui semiotika Roland Barthes yang dibatasi hanya pada pemaknaan tataran kedua yaitu: 1) Makna denotasi adalah makna secara langsung yang menuju kepada inti atau gambaran sebuah petanda. 2) Makna konotasi adalah suatu makna yang dihubungkan dengan kebudayaan sehingga makna konotasi akan menjadi semacam mitos atau mitos petunjuk (Berger, 2000: 55). Simbol dalam tari bersifat tesembunyi dan perlu interpretasi yang mendalam guna mengungkap maknanya. Seperti yang diungkapkan oleh Handayani (2017: 3) bahwa simbol yang terdapat pada sebuah karya yang diciptakan untuk menggungkapan makna yang tersembunyi.

\section{METODE}

Penelitian ini menggunakan metode penelitian kualitatif dengan pendekatan semiotika. Penelitian kualitatif menurut Sugiyono (2015: 14-15) metode penelitian kualitatif adalah metode penelitian yang berlandaskan pada filsafat postpositivisme (paradigma yang memandang realitas sosial sebagai sesuatu yang utuh, kompleks, dinamis, penuh makna, hubungan gejala bersifat interaktif). Metode ini digunakan mengingat objek yang diteliti merupakan suatu realita yang utuh dan komplek sehingga memenuhi filsafat postpositivisme berdasarkan pendapat Sugiyono.

Pendekatan semiotika yang digunakan adalah semiotika Roland Barthes yang membagi pemaknaan tanda menjadi dua yakni denotasi dan konotasi. Setiap elemen pertunjukan Tari Topeng Klana kemudian dianalisis ke dalam makna denotasi yaitu makna eksplisit yang terdapat pada unsurunsur tanda kemudian pemaknaan secara konotasi atau hasil interpretasi peneliti yang timbul ketika tanda bertemu dengan perasaan atau emosi peneliti (Kurniawan dalam Ardin 2017: 59).

Data dalam penelitian ini didapatkan menggunakan metode observasi, wawancara, dan dokumentasi. Observasi dilaksanakan pada tanggal 8 Februari 2019 dengan menggunakan teknik observasi partisipasi pasif. Observasi dilaksanakan guna mengamati pertunjukan. Wawancara dilaksanakan sembilan kali di bulan Februari 2019 dengan teknik wawancara terstruktur kepada Sukarta (cicit dari penyebar Tari Topeng hingga wilayah Priyangan, yakni Ki Wentar) dan Elang Mamat Nurahmat (ketua sanggar Kelapa Jajar dan seniman yang aktif dalam pentas Tari Topeng di wilayah Kota Cirebon) sebagai narasumber data primer, Ade Irfan (penari Tari Topeng Klana gaya Palimanan), Wiyono (seniman Tari Topeng dari gaya Slangit) dengan lima penonton sebagai narasumber data sekunder. Penonton yang berhasil peneliti wawancara, dua diantaranya memiliki rumah yang berdekatan dengan tempat latihan Tari Topeng Klana, sehingga sering mengapresiasi pertunjukan Tari Topeng Klana. Dokumentasi yang dilakukan adalah melakukan perekaman terhadap pentas Tari Topeng Klana dengan menggunakan kamera EOS $1100 \mathrm{D}$ sebagai dokumentasi peneliti serta mengumpulkan foto-foto yang dimiliki oleh penari topeng sebagai dokumentasi penelitian.

Data yang didapatkan kemudian diabsahkan melalui pengujian kredibilitas, transferabilitas dan dependabilitas. Pengujian kredibilitas dengan melakukan observasi dan wawancara berulangkali, triangulasi sumber dan waktu, meningkatkan ketekunan dan menggunakan bahan referensi. Pengujian trasferabilitas dengan menguraikan hasil-hasil penelitian dengan mendeskripsikan setiap elemen baik pelaku, gerak, suara atau musik, 
rupa yang meliputi busana dan sesaji serta lakon secara rinci, jelas, dan sistematis. Pengujian dependabilitas melakukan diskusi bersama auditor yang independen atau bersama dosen pembimbing.

Langkah selanjutnya setelah data yang didapatkan sah dan kredibel peneliti melakukan analisis data dengan mereduksi, menyajikan data dan menarik simpulan. Berikut langkah-langkah yang dilakukan peneliti dalam menganalisis data.

Reduksi data, peneliti melakukan pengetikan sehingga berbentuk naskah hasil wawancara. Peneliti tidak semua mengetik hasil wawancara. Selama proses wawancara, narasumber kadang bercerita dan keluar dari topik pembahasan, tetapi tetap terekam dalam rekaman wawancara. Pembicaraan yang keluar dari topik itulah peneliti tidak cantumkan dalam naskah hasil wawancara. Peneliti juga mengategorikan foto-foto hasil penelitian ke dalam beberapa folder sesuai dengan waktu pengambilan gambar dan sesuai dengan kategori seperti foto bagian gerak, foto bagian busana, dan foto bagian properti.

Penyajian data, peneliti melakukan interpretasi data yang didapatkan berbagai sumber, kemudian disajikan dalam bentuk paragraf deskriptif yang diawali dengan makna denotasi dan dilanjutkan deskripsi makna konotasi yang berkaitan dengan kehidupan manusia.

Penarikan simpulan, peneliti membandingkan hasil yang telah diketik dalam bentuk naskah setelah melakukan wawancara ke beberapa narasumber. Sebagian besar penuturan narasumber yang satu dengan yang lainnya memiliki kesamaan. Namun, ada beberapa perbedaan, apabila terdapat perbedaan hasil baik data yang diperoleh dari observasi, dokumentasi maupun wawancara dengan salah satu narasumber, maka peneliti menanyakan kembali kepada narasumber lain untuk meminta pendapatnya tanpa menyebutkan sumber data guna menghindari kesalahpahaman dan perbedaan pendapat.

\section{HASIL DAN PEMBAHASAN}

Pembahasan makna simbolik Tari Topeng Klana Cirebon gaya Palimanan dapat dianalisis menggunakan teori simbol oleh Susan K. Langer yang membagi simbol menjadi dua, yaitu simbol diskursif dan simbol presentasional. Kedua simbol kemudian dimaknai berdasarkan teori semiotika, Roland
Barthes yang membagi makna menjadi dua yaitu makna denotasi dan makna konotasi.

\section{Makna Simbol Diskursif Tari Topeng Klana Cirebon}

Makna diskursif merupakan makna yang terkandung dalam simbol-simbol yang terdapat pada unit-unit kecil pertunjukan Tari Topeng Klana Cirebon gaya Palimanan, artinya simbol-simbol itu terdapat dalam elemenelemen pertunjukan. Adapun elemen-elemen pertunjukan Tari Topeng Klana Cirebon gaya Palimanan menggunakan teori Kusmayati (dalam Cahyono 2006: 70) meliputi pelaku, gerak, bunyi atau suara, dan rupa. Soedarsono kemudian menambahkan unsur lakon dalam sebuah seni pertunjukan.

\section{Makna pada Elemen Pelaku Tari Topeng Klana Cirebon Gaya Palimanan}

Penyampaikan makna yang tersirat dalam sebuah pertunjukan tentunya diperlukan penyaji atau seniman baik secara langsung maupun tidak langsung dalam menyajikan pertunjukan.

Pelaku atau penari Tari Topeng Cirebon biasanya disebut sebagai dalang topeng. Tari Topeng Klana biasanya juga ditarikan oleh seorang perempuan, mengingat banyak dalang topeng perempuan dengan alasan ketidakadaan generasi dari dalang topeng sebelumnya. Namun, tak sedikit pula ada beberapa dalang topeng adalah seorang lakilaki. Berdasarkan hasil wawancara dengan Nurahmat tanggal 6 Februari 2019, pukul 14.40 WIB mengatakan bahwa dalang topeng harusnya seorang laki-laki. Hal ini dikonotasikan sebagai seorang penyiar agama, karena sejatinya Tari Topeng merupakan syiar Islam. Sangat jelas seorang penyiar adalah imam sehingga harus laki-laki.

\section{Makna pada Elemen Gerak Tari Topeng Klana Cirebon Gaya Palimanan}

Gerak dalam Tari Topeng Klana Cirebon terbagi menjadi tiga bagian yaitu dodoan, gancaran, dan deder. Gerak representatif dalam Tari Topeng Klana Cirebon gaya Palimanan yang terdapat di dalam ke tiga bagian meliputi sikap pasang/adeg-adeg, gerak pembuka, baksa sampur, peralihan dodoan, jangkung ilo, bango tong-tong, alung sumping, jajar kupat, geong sumping, gibas, pak bang, ngongkrak, sekar tiba, tumpang tali, nganggo kedok, ciluk, mondong, 
gedig, adu bapa, tumpak mobil, keprok, sonteg dan godeg akhir.

\section{Makna Sikap Pasang/Adeg-Adeg}

Pasang/adeg-adeg merupakan sikap kaki kedua kaki membuka sekitar $50 \mathrm{~cm}$ dengan kaki kiri menopang berat badan sedangkan kaki kanan sedikit maju dan samping kaki menghadap depan diikuti kedua lutut menekuk ke samping (denotasi). Pasang/adeg-adeg merupakan sikap kaki yang hampir banyak digunakan dalam menggerakan ragam gerak dalam Tari Topeng Klana Cirebon gaya Palimanan.

Sikap pasang/adeg-adeg harus kuat dan gagah dikonotasikan sebagai pamiangan (bahasa Sunda), niat yang kuat dalam mencapai suatu tujuan dan menghadapi dinamika kehidupan. Niat ditetapkan sebagai pedoman manusia dalam mencapai suatu tujuan sehingga tidak terjadi penyimpanganpenyimpangan saat proses berlangsung.

\section{Makna Gerak Pembuka}

Makna denotasi gerak pembuka dalam Tari Topeng Klana Cirebon gaya Palimanan merupakan serangkaian gerak untuk mengawali Tari Topeng Klana Cirebon gaya Palimanan yang terdiri atas gerak buka sampur, buang sumping dan gedig enam langkah. Makna konotasi dari gerak pembuka yang terdiri atas gerak buka sampur yang dikonotasikan sebagai buka pemikiran, buang sumping dikonotasikan sebagai menghilangkan segala hal yang menghambat kemudian gedig enam langkah dikonotasikan sebagai langkah persiapan atau masyarakat Cirebon mengatakan taki-taki.

\section{Makna Gerak Baksa Sampur \\ Baksa sampur adalah gerakan mengibas- ngibaskan sampur diatas kening baik menggunakan satu tangan maupun dua tangan dalam Tari Topeng Klana Cirebon gaya Palimanan (denotasi). Gerakan mengibas- ngibaskan sampur diatas kening dikonotasikan sebagai upaya mekanisme pemikiran. Hendaknya dalam mendapatkan sesuatu perlu melalui proses analisis sehingga tidak menelan mentah-mentah informasi yang didapatkan.}

\section{Makna Gerak Peralihan Dodoan \\ Gerak peralihan dodoan terdiri atas rangkaian gerak ambil sumping, tempel sekar, buang sumping, dan banting tangan (denotasi). Rangkaian peralihan gerak bagian dodoan}

dikonotasikan sebagai upaya memilih apa-apa saja yang kiranya baik atau buruk yang disimbolkan dengan gerak mengambil sumping dilanjutkan dengan berpikir sebelum melakukan sesuatu hal yang di lambangkan dengan menempelnya tangan ke sekar sebagai lambang akal atau budi.

Proses selanjutnya adalah mengimplementasikan pemikiran dengan tindakan-tidakan yang nyata yang tentunya sesuai dengan sasaran atau tujuan sejak awal ditetapkan yang dilambangkan dengan gerak buang sumping yang biasanya tepat dengan hitungan dla-pan atau gong.

Gerak peralihan dodoan diakhiri dengan banting tangan dengan menjulurkan tangan ke samping yang dikonotasikan sebagai wujud pengukuran kemampuan yang dimiliki oleh setiap manusia.

\section{Makna Gerak Jangkung Ilo}

Jangkung ilo merupakan gerak banting tangan yang dikombinasikan dengan mengkat salah satu kaki dengan telapak kaki setinggi setengah betis (makna denotasi). Makna konotasi dari gerak jangkung ilo adalah suatu usaha untuk melihat proses setelah manusia mencapai tujuan. Apabila ditinjau dari segi bahasa jangkung berarti tinggi dan ngilo berarti melihat, sehingga jangkung ilo dikonotasikan sebagai upaya peninjauan kembali terhadap proses yang mengiringi manusia sehingga manusia bisa berhasil mencapai tujuan. Perenungan terhadap proses dilakukan untuk menghindari sikap takabur atau sikap yang merasa paling mulia atau paling hebat diantara manusia yang lain.

\section{Makna Gerak Bango Tong-Tong}

Gerak bango tong-tong didenotasikan sebagai gerak naik turun yang dikombinasikan dengan gerak ketika naik dengan tutup sampur kedua tangan diatas kening dan ketika turun dikombinasikan dengan kedua tangan malangkerik. Gerak naik dan turun dalam bango tong-tong dikonotasikan sebagai wujud kehatihatian dalam menjalankan sesuatu hal. Sukarta mengatakan aja padu krayak-krayak bae dalam menjelaskan makna gerak bango tong-tong. Perkataan tersebut bermakna bahwa apabila manusia berjalan jangan sembarangan, penuh pertimbangan agar setiap langkah dan setiap keputusan yang diambil kiranya baik untuk setiap pihak yang terlibat. Pernyataan tersebut relevan dengan falsafah hidup orang Jawa, 
yakni alon-alon waton kelakon yang memiliki makna berhati-hati dalam setiap melakukan suatu hal, perhitungan, cermat, dengan dasar atau waton atau tujuan yang jelas sehingga akan memperoleh hasil yang optimal (Ariyiliyanto, 2013: 3).

\section{Makna Gerak Alung Sumping \\ Gerak alung sumping didenotasikan sebagai gerak melempar sumping dengan tangan kanan dilanjutkan gerak seblak sampur oleh tangan kiri dengan posisi kaki pasang/adeg-adeg. Konotasi gerak alung sumping adalah manusia hendaknya memiliki prioritas terhadap kepentingan-kepentingan yang ada pada dirinya. Meprioritaskan suatu kepentingan terkait dengan manajemen waktu. Hendaknya manusia mendahulukan mana yang dianggap penting dibandingkan dengan kepentingan yang lain dalam rangka mencapai suatu tujuan.}

\section{Makna Gerak Jajar Kupat}

Gerak jajar kupat adalah gerak melurustekukkan tangan di depan dada dikombinasikan gerak kaki mentul-mentul. Gerak jajar kupat dilakukan dengan santai menikmati iringan yang membuat enjoy. Gerak menikmati alunan iringan dikonotasikan dengan memberikan kenyamanan terhadap manusia lain agar tidak merasa tertekan jika berada di sekeliling kita. Termasuk didalamnya menciptakan suasana yang kondusif dalam berkomunikasi guna menciptakan kehidupan sesama manusia yang saling mempengaruhi.

\section{Makna Gerak Geong Sumping \\ Gerak geong sumping adalah gerak menoleh ke kanan dan ke kiri dengan menunduk sehingga sumping yang menjuntai ke bawah nampak berayun-ayun, sedangkan posisi kedua tangan malangkerik dan kaki melakukan langkah ganda dengan volume kecil. Gerak geong sumping dikonotasikan sebagai pengolahan pemikiran, dan mengatur strategi sehingga mencapai suatu hasil yang maksimal. Olah pemikiran dalam melakukan sesuatu hal artinya tidak menelan secara kasar terhadap sesuatu yang didapatkan, atau perlu adanya telaah terhadap hal-hal yang datang sehingga selanjutnya dapat dipilih mana yang terbaik dalam rangka mencapai suatu tujuan.}

\section{Makna Gerak Gibas}

Gerak gibas adalah gerak tangan melambai ke atas dengan satu tangan menekuk di depan kening dengan jarak kening dan jari sekitar $15 \mathrm{~cm}$ sementara tangan yang satu lurus sedikit rendah menyerong dan diakhiri gerak banting tangan (makna denotasi). Makna konotasi dari gerak gibas adalah menjelaskan sesuatu memberi petunjuk kepada manusia lain secara detail dan tuntas hingga pada pengaplikasiannya. Manusia sebagai makhluk yang memiliki pengetahuan apabila dibutuhkan oleh manusia lain, hendakanya mampu memberikan penjelasan hingga kepada pengaplikasian dan penerapannya sehingga tidak terjadi kesalahan pada pengaplikasian yang berujung pada ketidakmaksimalan tujuan yang hendak dicapai.

\section{Makna Gerak Pak Bang}

Gerak pak bang didenotasikan sebagai kombinasi gerak capang dan banting tangan diikuti dengan dua langkah maju atau mundur dengan gerakan yang tegas diikuti kepala menoleh ke kanan dan ke kiri secara tegas (makna denotasi). Makna konotasi gerak pak bang dapat dilihat pada arti kata pak bang yaitu kudu napak ning lebange, artinya harus berpijak pada tempatnya. Maksudnya adalah fleksibilitas sikap manusia dalam melakukan kehidupan untuk mencapai suatu tujuan. Manusia hendaknya bersifat fleksibel atau dapat menyesuaikan dimana saja manusia itu berada.

\section{Makna Gerak Ngongkrak}

Ngongkrak adalah gerak kaki double step atau langkah ganda dengan volume ruang yang kecil dikombinasi dengan gerak tangan capang atau lurus tekuk di depan dada (makna denotasi). Gerak ngongkrak dilakukan dengan semangat dan tegas. Gerak ngongkrak dikonotasikan sebagai gairah atau semangat dalam mengejar suatu tujuan. Pentingnya semangat dalam mampu terus mendorong diri untuk konsisten dalam mengejar sesuatu yang diharapkan dengan menghilangkan segala bentuk kelalaian yang akan mengurangi kemaksimalan hasil yang akan dicapai.

\section{Makna Gerak Sekar Tiba}

Gerak sekar tiba adalah gerakan menempelkan satu atau dua tangan ke sekar dilanjutkan dengan membolak-balikan tangan disamping jika menempelkan satu tangan ke 
sekar dan membolak-balikan tangan di depan pusar jika menempelkan kedua tangan ke sekar diikuti dengan sikap kaki pasang/adeg-adeg (makna denotasi). Makna konotasi gerak sekar tiba adalah sebagai wujud kontemplasi atau perenungan. Wujud kontemplasi atau perenungan dapat dilihat ketika penari melakukan gerak menempelkan sekar dilanjutkan dengan membolakbalikan tangan. Wujud perenungan dalam bahasa sunda disebut dibeuweung, diutahkeun, atau dilenyepi.

\section{Makna Gerak Tumpang Tali}

Gerak tumpang tali adalah gerak pergelangan tangan bertumpuk di depan dada dengan tangan kanan diatas dan tangan kiri dibawah sementara posisi jari tangan menghadap depan kemudian dirangkai dengan gerak banting kedua tangan (makna denotasi). Gerak tumpang tali dikonotasikan sebagai upaya pemeliharaan ilmu. Manusia yang memiliki ilmu hendaknya dipelihara atau diikat dengan kencang layaknya mengikat sebuah tali. Pemeliharaan ilmu dilalui dengan cara dipelajari, didalami, dipahami, bahkan hingga disebarkan kepada orang lain.

\section{Makna Gerak Nganggo Kedok}

Gerak nganggo kedok adalah gerak memakai topeng dalam Tari Topeng Klana Cirebon gaya Palimanan. Gerak nganggo kedok dilakukan pada bagian deder setelah gerak tumpang tali. Gerak bagian dododan hingga gancaran, penari tidak menggunakan topeng, ketika mulai memasuki musik deder penari memakai topeng yang masih terbungkus ules. Gerak nganggo kedok atau memakai topeng dikonotasikan sebagai kamuflase. Manusia ketika dalam menjaga hubungan habluminannas atau hubungan dengan sesama manusia perlu menggunakan topeng atau kamuflase. Kamuflase yang dimaksud adalah fleksibilitas dalam menata sikap agar dapat diterima oleh masyarakat umum. Seperti yang dikatakan Jaeni bahwa orang selalu memakai topeng atau berpura-pura untuk menampilkan jati diri yang dikehendaki (2014: 34).

\section{Makna Gerak Ciluk}

Gerak ciluk didenotasikan sebagai gerak membuka dan menutup wajah yang sudah menggunakan topeng dengan kedua tangan yang memegang ujung sampur (makna denotasi). Gerak membuka dan menutup wajah dikonotasikan sebagai realisasi sikap atau suatu pembuktian dengan menggunakan aksi atau tindakan nyata agar tampak seperti apa yang diungkapkan oleh lisan atau diungkapkan melalui visualisasi penampilan. Terkadang manusia hanya menilai seseorang hanya berdasarkan penampilan secara kasat mata tanpa menelisik kebenarannya.

Makna Gerak Mondong

Gerak mondong adalah gerak seperti menyerudut dengan kedua tangan merentang namun sedikit direndahkan dengan sikap kedua kaki pasang/adeg-adeg (makna denotasi). Gerak mondong apabila dikaitkan dengan kisah Klana Menakjingga yang kasmaran dengan Ratu Kencanawungu adalah upaya menyenangkan hati Ratu Kencana Wungu agar tergoda dan tertarik dengan Klana Menakjingga. Gerak menyerudut dengan kedua tangan membentang ini dikonotasikan sebagai upaya menyenangkan hati orang lain yang masyarakat Cirebon menyebutnya nyenyeneng uwong. Kehidupan manusia tidak dapat berjalan tanpa campur tangan manusia lain. Sehingga dalam berkehidupan manusia hendaknya saling menjaga sikap dan perilaku yang mungkin bisa membuat tidak nyaman orang lain. Hal menyenangkan hati orang lain guna menciptakan hubungan bermasyarakat harmonis dan bisa saling memenuhi kebuTuhan satu sama lain atau simbiosis mutualisme.

\section{Makna Gerak Gedig}

Gerak Gedig merupakan gerak melangkah dengan volume besar yang didahului kaki mengangkat dengan telapak kaki setinggi lutut diikuti dengan tangan membentang dan mengepal (makna denotasi). Gerak gedig dikonotasikan sebagai kepastian langkah seseorang dalam mencapai suatu tujuan. Sukarta menjelaskan bahwa pemaknaan gedig dengan kepastian langkah dapat dilihat pada gerak langkah gedig yang tegas dan pasti. Gerak gedig merupakan cerminan bahwa manusia hendaknya menentukan langkah sejak awal untuk mencapai suatu tujuan. Langkahlangkah tersebut disusun sebagai pedoman selama proses mencapai tujuan. Pedoman digunakan sebagai peta ketika manusia mengalami ketersesatan dalam mencapai tujuan.

\section{Makna Gerak Adu Bapa}

Gerak adu bapa merupakan gerak seperti menyikut yang diikuti tolehan kepala ke kanan 
apabila gerak menyikut ke kanan dan tolehan kepala ke kiri apabila gerak menyikut ke kiri (makna denotasi). Gerak adu bapa dikonotasikan sebagai melihat sekitar atau melihat kanan kiri kepada sesuatu yang berada di lingkungan kehidupan manusia. Sukarta dalam wawancara 17 Februari 2019 pukul 12.34 WIB mengatakan bahwa adu bapa berarti tilak-tilik (bahasa Cirebon) yang menyiratkan bahwa sebelum mengerjakan sesuatu atau hendak menetapkan tujuan, seyogyanya manusia melihat sekitar atau kanan dan kiri yang sekiranya memberi manfaat atau tidak bagi kehidupan sekitar.

\section{Makna Gerak Tumpak Mobil}

Gerak tumpak mobil adalah gerak mengangkat tangan kanan ke atas dengan telapak tangan dan kepala menengadah ke atas dan dilanjutkan dengan gerak ogek lambung pada gerak ini terdengar senggakan yang disorakkan oleh nayaga yakni "tumpak mobil Bandung". Gerak kemudian dilanjutkan dengan kedua tangan malangkerik pada cethik kiri diikuti kaki mantul-mantul dan terdengar senggakan yang berbunyi "tumpak mobil bobrok" (denotasi). Dua rangkaian gerak yang berbeda dalam gerak tumpak mobil dikonotasikan sebagai upaya perhitungan yang matang. Manusia dalam menghadapi kehidupan selalu berhadapan dengan pilihan-pilihan yang tentu memiliki positif dan negatif, sehingga perlu menentukan keputusan terhadap pilihan dalam mencapai suatu tujuan dengan mempertimbangkan efektivitas. Seperti biaya, waktu, tenaga, maupun hal-hal lain dalam mencapai suatu tujuan.

\footnotetext{
Makna Gerak Keprok

Keprok merupakan gerak dengan kedua tangan keatas menyatukan telapak tangan layaknya bertepuk tangan (denotasi). Gerakan seperti bertepuk tangan diatas dikonotasikan sebagai perasaan yang jangan pernah merasa puas atas pencapaian yang diperjuangkan. Manusia hendaknya merasa kurang agar timbul obsesi untuk terus menggali. Perasaan yang merasa kurang secara terus-terusan akan menghambat sifat sombong timbul. Sehingga sebagai manusia perlu belajar dari tanaman bambu yang semakin tinggi maka semakin melengkung ke bawah artinya semakin seseorang memiliki ilmu maka ia semakin merendah dan semakin merasa kekurangan terhadap hasil ilmu yang ia dapatkan.
}

\begin{abstract}
Makna Gerak Sonteg
Sonteg merupakan perpaduan rangkaian gerak menempelkan kedua tangan ke sekar kemudian meluruskan tangan ke bawah dengan langkah kaki dan diakhiri kedua tangan malangkerik dan anggukan kepala secara tegas (makna denotasi). Gerak sonteg dilakukan dengan berjalan ke kanan yang diakhiri dengan anggukan kepala secara tegas kemudian berjalan ke kiri yang diakhiri dengan anggukan secara tegas pula. Gerak sonteg yang ke kanan dan ke kiri diakhiri dengan gerak yang sama dikonotasikan sebagai bentuk keseimbangan. Manusia hendaknya menyeimbangkan segala sesuatu dengan keadaan atau realita sebelum menetapkan suatu tujuan.
\end{abstract}

\section{Makna Gerak Godeg Akhir \\ Godeg akhir merupakan gerak menggelengkan kepala secara cepat dengan tangan kanan memegang ujung sumping dan tangan kiri lurus ke depan dengan posisi jari ngrayung namun ibu jari tidak menempel pada telapak tangan (makna denotasi). Gerak godeg akhir merupakan gerak yang terakhir sebelum memasuki gerak penutup sehingga dikonotasikan sebagai bentuk evaluasi setelah manusia mencapai keberhasilan dalam mencapai tujuan. Evaluasi dilakukan agar manusia tidak melupakan proses yang berharga terhadap siapapun yang menemani proses menuju keberhasilan suatu tujuan.}

\section{Makna pada Elemen Musik Tari Topeng Klana Cirebon Gaya Palimanan}

Tari Topeng Klana Cirebon diiringi dengan satu set gamelan berlaras pelog yang terdiri atas Saron dua pangkon, Penerus satu pangkon, Peking atau Pipil, Bonang, Rincik atau kemyang, Kenong Njeglong, Kebluk, Gong, Beri atau Kecrek, Kendang dan kadang ditambah seruling. Gendhing pengiring Tari Topeng Klana menggunakan gendhing gonjing yang terbagi menjadi tiga tempo yakni dodoan, gancaran/rancag, dan deder.

Nama gonjing hampir dipadupadankan dengan sebuah makanan yang terbuat dari tepung beras dengan parutan kelapa yang dibuat menyerupai setengah lingkaran dengan alas yang melengkung atau kue bandros (Sunda), kue pancong (Indonesia). "Ya gonjing itu kaya makanan yang dibuat miring" demikian Sukarta ketika awal menjelaskan konotasi dari makna gendhing gonjing (wawancara 5 Februari 2019 pukul 12.40 
WIB). Gendhing gonjing apabila dikonotasikan menggambarkan suatu kemiringan yang perlu mendapat kesetimbangan apabila terdapat sesuatu yang baru. Layaknya manusia apabila mendapat suatu perubahan, baik sosial, budaya maupun perubahan apapun yang dirasa kurang sesuai dengan paradigma awalnya, maka manusia secara tidak langsung akan menyesuaikan terhadap paradigma yang baru.

\section{Makna pada Elemen Rupa Tari Topeng Klana Cirebon Gaya Palimanan}

Rupa dalam pertunjukan menurut Kusmayati (2000: 90) meliputi busana, properti dan sesaji yang mewujudkan suatu peristiwa. Begitu pula dalam Tari Topeng Klana Cirebon yang dalam pertunjukannya terdapat rupa berupa busana, properti dan sesaji yang memiliki makna-makna khusus. Namun seiring berkembangnya zaman busana, properti dan sesaji tidak dapat ditemukan pada setiap kesempatan pertunjukan Tari Topeng Klana.

\section{Makna Busana Tari Topeng Klana}

Penggunaan Busana Tari Topeng Klana dapat dilihat pada foto 1 berikut.
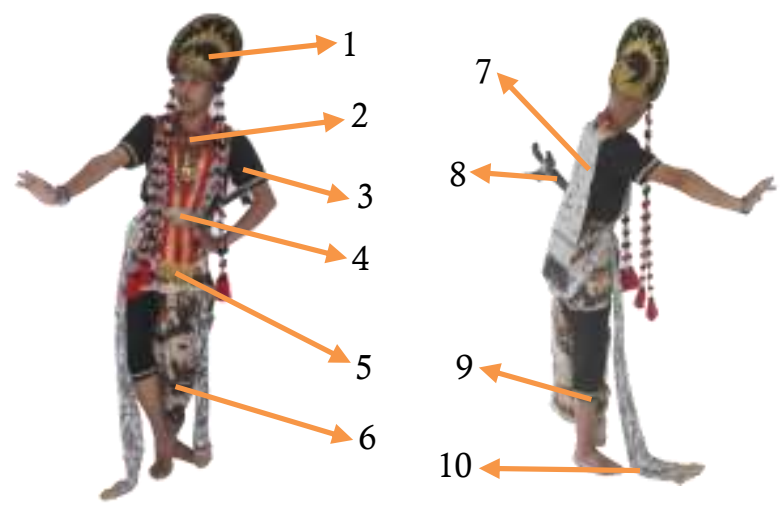

Foto 1. Busana Tari Topeng Klana (Sumber: Martino, 2019)

Foto 1 memperlihatkan bahwa busana Tari Topeng Klana terdiri atas 1) Sobrah, 2) Ombyok, 3) Baju kutung, 4) Badong, 5) Kace, 6) Kain dodot lancar cangcut, 7) krodong, 8) Keris, 9) Celana sontog, 10) Sampur/Soder. Namun, hanya beberapa yang mamiliki makna khusus.

\section{Makna Sobrah}

Sobrah merupakan asesoris yang dipasang di bagian kepala yang disamping kanan dan kirinya terdapat sumping atau bulatan-bulatan kecil yang menjuntai hingga paha, serta jamang yang terbuat dari kulit kerbau dipasang menghiasi bagian depan dan belakang serta jika dipasang pada bagian kening terdapat dua lingkaran kecil yang bernama picis (denotasi). Bentuk sobrah dapat dilihat pada foto 1 berikut.

Sobrah dikonotasikan sebagai lambang kesabaran apabila dilihat pada pembentukan kata sobrah. Kata sobrah berasal dari kata sobir, sobur, sobaro, sobron yang berarti sabar (Suanda 2009: 188). Bagian-bagian sobrah dapat dilihat pada foto 2 berikut.

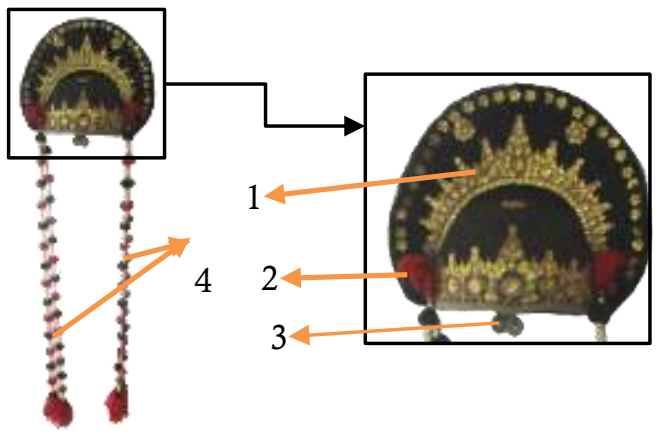

Foto 2. Bagian-Bagian Sobrah

(Sumber: Martino, 2019)

Foto 2 memperlihatkan bahwa sobrah terdiri atas 1) Jamang, 2) Sekar, 3) Picis, dan 4) Rawis/Sumping yang memiliki makna konotasi masing-masing.

Sekar dikonotasikan sebagai buah pemikiran manusia (Suanda, 2009: 188), sehingga banyak gerak Tari Topeng Klana Cirebon yang menempelkan tangan ke sekar sebagai simbol anjuran kepada manusia agar selalu menggunakan pikiran atau memikirkan segala sesuatunya dengan matang sebelum bertindak sesuai dengan pendapat Wardhama dalam Hartono (2002: 4) yang menyatakan bahwa manusia yang berbudi pekerti luhur adalah manusia yang sikap dan perilakunya didasarkan pada akal sehat yaitu tutur kata, gerak-gerik dan tata krama yang baik.. Pada bagian sekar dibawahnya menjuntai bulatanbulatan kecil yang disebut sebagai sumping atau rawis. Jumlah bulatan-bulatan kecil dalam sumping adalah sembilan buah sebagai lambang sembilan lubang yang ada pada tubuh manusia: dua mata, dua lubang hidung, satu mulut, dua telinga, satu dubur dan satu qubul. Interpretasi berlanjut apabila dikaitkan dalam gerak mengambil sumping kemudian melemparnya. Hal ini dimaknai sebagai sebuah cerminan bahwa manusia hendaknya menjaga sembilan lubang yang ada di dalam dirinya dengan menggunakannya untuk hal-hal yang positif kemudian menyingkirkan segala 
hal-hal yang kiranya mengganggu berupa nafsu negatif sehingga tujuan hidup dapat tercapai. Selain itu Nurahmat (wawancara 12 Februari 2019 pukul 11.34 WIB) mengatakan bahwa peletakan sumping di kanan dan kiri merupakan lambang manusia yang selalu diawasi di bagian kanan dan kiri atau oleh malaikat raqib dan atid yang setia mencatat amal manusia untuk dipertanggungjawabkan di akhirat kelak.

Bagian depan sobrah terdapat picis dan jamang yang memiliki puncak seolah-olah menunjuk keatas. Picis merupakan lambang paningal atau penglihatan manusia. Picis dipasang lurus dengan puncak jamang seolaholah membentuk satu garis yang lurus apabila ditarik garis vertikal (lihat gambar 2 nomor 3). Hal ini dikonotasikan bahwa dalam menjalani kehidupan manusia hendaknya memiliki satu pandangan atau keyakinan terhadap keesaan Tuhan, Sukarta (wawancara 19 Oktober 2017) menyebutnya ojo mangro tingal (jangan memiliki dua pandangan) atau jangan percaya selain kepada kekuatan Tuhan.

Makna Baju Kutung dan Celana Sontog yang Berwarna Hitam

Baju kutung merupakan baju yang berwarna hitam dengan panjang lengan setengah lengan atas. Baju kutung memiliki kancing di depan yang hanya sebatas pangkal leher hingga dada. Celana sontog merupakan celana berwarna hitam yang panjangnya di bawah lutut. Baju kutung dan celana sontog terbuat dari kain sateen yang pada ujung lengan dan kakinya dipasang renda berwarna emas.

Penggunaan warna hitam sebenarnya hampir terdapat dalam beberapa elemen selain pada baju kutung dan celana sontog. Warna hitam yang merupakan yang sering diidentikan dengan warna tanpa cahaya atau kegelapan dalam konteks ini dimaknai sebagai simbol nafsu yang menurut Parmono (1995: 32) melanjutkan penjelasan apabila manusia mampu menahan nafsu maka akan menjadi manusia yang teguh dan berbudi pekerti luhur. Apabila dikaitkan dengan Tari Topeng Klana, manusia hendaknya memiliki nafsu dalam mengejar tujuan hidup, nafsu yang dimaksud tentunya memiliki konotasi yang positif seperti gairah atau semangat dalam mengejar suatu tujuan.
Makna Penggunaan Sampur atau Soder

Penggunaan sampur dalam Tari Topeng Klana Cirebon yaitu dililitkan pada badong atau ikat pinggang sehingga menjuntai pada bagian kanan dan kiri pinggang penari. Pemakaian sampur dibuat sengaja tidak seimbang dengan sebelah kanan yang lebih panjang. Hal itu dilakukan sebagai keperluan gerak sepak soder atau gerak menendang sampur menggunakan kaki kanan.

Suanda (2009: 192) mengonotasikan penggunaan sampur atau soder sebagai perasaan hati manusia ketika ada keinginan untuk membuang hawa nafsu duniawi. Namun, perasaan itu hanya bersifat sementara dan akan tetap hadir dalam hati manusia. Hal tersebut terlihat dari bagaimana penari membuang sampur atau soder, sampur atau soder tersebut akan kembali menjuntai di bagian pinggang kanan dan kiri penari yang juga dalam Tari Topeng Klana.

Suanda (2009: 190) menyatakan bahwa dalam Tari Topeng Panji tidak melakukan gerak menendang sampur atau soder baik ke belakang maupun ke depan. Namun dalam Tari Topeng Klana sering menjumpai penari menendang sampur atau soder dengan menggunakan kaki kanan. Mengingat Tari Topeng Cirebon menggambarkan siklus kehidupan manusia atau beranjaknya manusia dari usia ke usia, sehingga menurut interpretasi Peneliti bahwa ketidakadaan gerak menendang sampur atau soder dalam Tari Topeng Panji adalah mengingat Tari Topeng Panji yang menggambarkan bayi yang baru lahir sehingga nafsu duniawi manusia hanya sebatasnya. Berbeda dengan Tari Topeng Klana yang menggambarkan puncak kedewasaan manusia dengan segala kematangan akan memiliki nafsu duniawi yang semakin beragam dan kompleks. Pose gerak menendang sampur dapat dilihat pada foto 3 berikut.

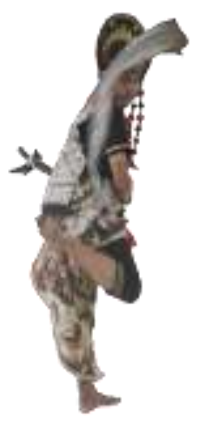

Foto 3. Pose Penari Menendang Sampur/Soder (Sumber: Martino, 2019) 


\section{Makna Penggunaan Tapih Lancar Cangcut}

Penggunaan kain dodot lancar cangcut yang hanya menutupi kaki kanan penari hingga atas mata kaki dan kaki kiri hanya sebatas paha (denotasi) merupakan lambang raja laki-laki yang memiliki kekuasaan yang agung (konotasi) seperti kedudukan dalang topeng dimata masyarakat yang dianggap memiliki kekuatan tersendiri dalam mendatangkan berkah dan keselamatan hidup (Dyah 2007: 244). Bahkan ada beberapa masyarakat yang membawa anak mereka yang sakit kemudian dimintakan doa kesembuhan kepada dalang topeng.

\section{Makna Properti Tari Topeng Klana Cirebon}

Jazuli (2016: 62) membagi properti atau perlengkapan menjadi dua macam, yaitu dance property dan stage property. Seperti dalam Tari Topeng Klana yang memiliki dance property berupa topeng dan kain ules. Sedangkan stage property berupa gantungan dan kotak topeng.

\section{Makna Kedok dan Ules}

Kedok Klana memiliki warna dasar merah dengan mata yang melotot lebar, alis yang bergelombang, hidung yang mancung dan lancip memanjang ke depan disertai dengan kumis yang amat tebal. Senyumnya melebar memperlihatkan gigi-giginya yang besar. Tak jauh di area bibir terdapat dagu yang dipenuhi warna hitam sebagai motif dari brengos. Ekspresi yang ditimbulkan oleh wajah Klana memunculkan kesan gagah, berani dan garang dikonotasikan sebagai sikap yang berani dalam menghadapi risiko untuk mencapai tujuan hidup.

Kain ules merupakan kain yang berwarna merah dengan panjang 20x30 cm (makna denotasi). Kain ules digunakan untuk menutupi topeng yang dikonotasikan sebagai peringatan kepada manusia atas ketidakberdayaan ketika masih bayi. Manusia diajak untuk merenungi atas ketidakberdayaan ketika masih berada dalam kandungan. Sungguh terbatasnya dan terikatnya bayi ketika berada di dalam kandungan sehingga sebagai manusia tidak ada hal yang patut dibanggakan melainkan penuh ketidakberdayaan. Kedok Klana dan kain ules dapat dilihat pada foto 4 berikut.

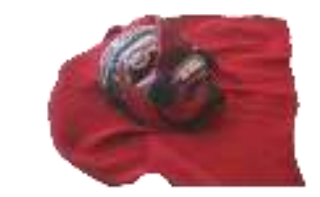

Foto 4. Kedok Klana dan Ules (Sumber: Martino, 2019)

\section{Makna Gantungan}

Gantungan adalah berbagai macam palawija seperti pisang, kerupuk, singkong, kacang panjang, pare, oyong, terong ungu, terong hijau, rengginang, dan jagung mentah. Komposisi yang terdapat dalam gantungan disediakan oleh pemangku hajat sebagai wujud sedekah (makna denotasi). Gantungan dapat dilihat pada foto 5 berikut.

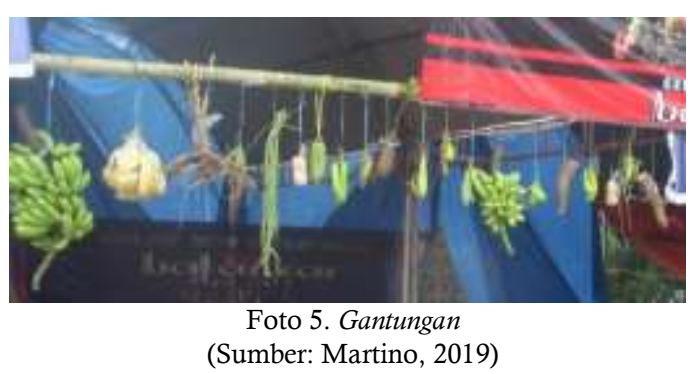

Gantungan dikonotasikan sebagai wujud keramaian alam. Manusia hendaknya selalu menjaga keseimbangan alam dengan merawat tanpa merusak alam yang selalu memberi manfaat untuk menopang kehidupan manusia. Selain itu, pemasangan gantungan juga dikonotasikan sebagai pengingat asal manusia yang berasal dari tanah. Segala bentuk palawija dan makanan yang ada di alam dimakan oleh manusia yang kemudian menjadi sari yang disebut sebagai sari pati atau air sperma yang merupakan asal-muasal manusia.

\section{Makna Kotak Topeng}

Sesuai dengan namanya, kotak topeng berbentuk kotak atau kubus yang terbuat dari kayu dengan panjang sekitar $60 \mathrm{~cm}$, lebar 40 $\mathrm{cm}$ dan tinggi sekitar $50 \mathrm{~cm}$ (makna denotasi).

Saat sebelum penari memulai tarian, dalang topeng biasanya menghadap kotak topeng dengan duduk bersila. Kemudian penari berdiri dan memulai gerak tari dan diakhiri dengan kembali menyimpan topeng ke dalam kotak. Praktik tersebut menurut Suanda (2009: 203) menggambarkan bahwa kotak topeng sebagai simbol pamiangan dan pangbalikan. Artinya manusia harus tahu dari 
mana berasal dan harus tahu pula ke mana ia harus kembali. Manusia tentunya harus memiliki pedoman untuk dapat mengetahui asal dan kemana ia kembali. Sehingga dalam proses perjalanan hidupnya ia tidak tersesat. Demikian dengan Tari Topeng Klana sebagai wujud puncak manusia dengan segala apapun yang dimilikinya agar tetap berpedoman dalam mengejar tujuan hidup agar tahu kemana ia harus kembali setelah tujuan itu tercapai.

\section{Makna Sajen}

Berdasarkan pendapat Endraswara (2003: 195) Sesaji adalah wujud aktualisasi dari pikiran keinginan dan perasaan pelaku untuk lebih mendekatkan diri kepada Tuhan. Perlengkapan sajen dalam pertunjukan Tari Topeng Cirebon terdapat tumpeng, ayam yang dipanggang, ketupat, lepet, tantang angin, kelapa muda, dan wedang rerujakan (denotasi). Adapun makna konotasi dari masing-masing elemen sesaji dapat dilihat pada tabel 1 berikut.

Tabel 1. Makna elemen sesaji

\begin{tabular}{|c|c|c|}
\hline $\begin{array}{c}\text { Elemen } \\
\text { Sesaji }\end{array}$ & $\begin{array}{c}\text { Makna } \\
\text { Denotasi }\end{array}$ & $\begin{array}{c}\text { Makna } \\
\text { Konotasi }\end{array}$ \\
\hline Tumpeng & $\begin{array}{l}\text { Nasi yang } \\
\text { berbentuk } \\
\text { kerucut. }\end{array}$ & $\begin{array}{l}\text { Menyerahkan segala } \\
\text { sesuatunya kepada } \\
\text { Tuhan. }\end{array}$ \\
\hline $\begin{array}{l}\text { Ayam } \\
\text { bekakak }\end{array}$ & $\begin{array}{l}\text { Ayam yang } \\
\text { dipanggang } \\
\text { dengan bentuk } \\
\text { terbuka dan } \\
\text { telah dibuang } \\
\text { segala jeroan } \\
\text { atau isi perut } \\
\text { yang ada } \\
\text { didalamnya }\end{array}$ & \begin{tabular}{lr}
\multicolumn{2}{l}{ Membersihkan niat } \\
segala & sesuatunya \\
untuk & tujuan \\
ibadah. &
\end{tabular} \\
\hline $\begin{array}{l}\text { Kupat, } \\
\text { lepet, } \\
\text { tantang } \\
\text { angin }\end{array}$ & $\begin{array}{l}\text { Makanan } \\
\text { tradisional } \\
\text { yang terbuat } \\
\text { dari beras dan } \\
\text { ketan. }\end{array}$ & \begin{tabular}{lr}
\multicolumn{2}{l}{ Simbol pertemuan } \\
rwa binedha yang \\
melahirkan manusia \\
dengan segala \\
kehendak yang \\
dipanjatkan.
\end{tabular} \\
\hline $\begin{array}{l}\text { Buah } \\
\text { sarwa } \\
\text { gumantung } \\
\text { dan sarwa } \\
\text { kapendem }\end{array}$ & $\begin{array}{l}\text { Buah-buahan } \\
\text { yang } \\
\text { menggantung } \\
\text { dan terpendam } \\
\text { di dalam } \\
\text { tanah. }\end{array}$ & $\begin{array}{l}\text { Menuju suatu } \\
\text { keberhasilan atau } \\
\text { kesuksesan melalui } \\
\text { perjuangan atau } \\
\text { proses yang panjang } \\
\text { atau terpendam } \\
\text { terlebih dahulu. }\end{array}$ \\
\hline $\begin{array}{l}\text { Wedang } \\
\text { Rerujakan }\end{array}$ & $\begin{array}{l}\text { Air putih dan } \\
\text { beberapa air } \\
\text { yang memiliki } \\
\text { rasa seperti teh } \\
\text { dan kopi. }\end{array}$ & $\begin{array}{l}\text { Pelengkap } \\
\text { kehidupan bahwa } \\
\text { manusia tidak dapat } \\
\text { hidup tanpa adanya } \\
\text { air yang selalu } \\
\text { memberi manfaat } \\
\text { bagi kehidupan. }\end{array}$ \\
\hline $\begin{array}{l}\text { Degan } \\
\text { (kelapa } \\
\text { muda) }\end{array}$ & $\begin{array}{l}\text { Kelapa muda } \\
\text { yang di kikis } \\
\text { kulit bagian } \\
\text { atasnya } \\
\text { sehingga } \\
\text { mengerucut. }\end{array}$ & $\begin{array}{l}\text { Air tersuci yang } \\
\text { diciptakan oleh } \\
\text { Tuhan. }\end{array}$ \\
\hline
\end{tabular}

\section{Makna pada Elemen Lakon Tari Topeng Klana Cirebon}

Tari Topeng Klana mengisahkan cinta seorang Raja Blambangan bernama Prabu Klana Menakjingga yang jatuh cinta dengan Ratu Kencana Wungu atau Rahwana yang mengejar Dewi Shinta (makna denotasi). Kisah Rahwana yang mencintai Dewi Shinta jauh lebih populer di telinga masyarakat dibandingkan kisah Klana Menakjingga yang mengejar Ratu Kencana Wungu. Berdasarkan pendapat narasumber, sebenarnya sah-sah saja apabila menyebut Tari Topeng Klana sebagai tokoh Rahwana. Namun, apabila merunut kisah utuhnya, maka Tari Topeng Klana menceritakan alam Panji, yakni Klana Menakjingga.

Klana Menakjingga dan Rahwana merupakan dua sosok raja yang tujuannya atau cintanya tidak dapat tersampaikan. Namun, apabila ditelisik lebih dalam, timbul suatu sikap untuk tetap mempertahankan martabatnya sebagai raja dari sudut pandang yang berbeda-beda dan akhirnya menjadi pembelajaran bagi manusia untuk tetap berada pada rel atau pedomannya sebagai manusia dalam mencapai tujuan hidupnya (konotasi). Klana Menakjingga memilih jalur perang ketika cintanya ditolak oleh Ratu Kencana Wungu, memang terdengar sangat kejam dan tidak manusiawi dan terkesan menghalalkan segala cara. Oleh karena itu, sebagai manusia jangan mengambil sisi yang demikian, namun ambilah sisi Klana Menakjingga yang sebagai raja dalam memilih jalur perang, artinya lebih menunjukkan kekuatan dirinya untuk mempertahankan martabatnya agar tidak dicap sebagai raja yang pengecut atau beraninya hanya menculik. Begitupun manusia hendaknya memilih jalur terbaik dalam mencapai tujuan hidup agar martabatnya sebagai manusia tidak dianggap rendah oleh manusia lain. Rahwana pun demikian, setelah berhasilnya menculik Dewi Shinta dan menyanderanya di Alengka, Rahwana tetap mempertahankan martabatnya sebagai raja. Rahwana sama sekali tidak gegabah bahkan tak sedikitpun menyentuh Dewi Shinta dan tetap mempertahankan kehormatan Dewi Shinta sebagai seorang perempuan. Artinya Rahwana tetap mempertahankan martabatnya sebagai raja dengan tidak melecehkan Dewi Shinta. Demikian pula dengan manusia hendaknya tetap mempertahankan 
martabatnya untuk tidak gegabah dalam memilih suatu jalan mencapai tujuan hidup.

\section{Makna Simbol Presentasional Tari Topeng Klana Cirebon gaya Palimanan}

Tari Topeng Klana merupakan tarian yang menggunakan topeng Klana yang diiringi dengan gendhing gonjing dengan gerakan enerjik dan penuh semangat (makna denotasi). Gerak yang muncul dan dari beberapa gabungan simbol-simbol diskursif lain mengonotasikan bahwa Tari Topeng Klana menggambarkan semangat manusia dalam mengejar tujuan hidup. Sehingga dalam praktiknya Tari Topeng Klana ditarikan dengan penuh kegagahan, hal ini dikonotasikan gagah dalam mengejar suatu tujuan yang mengharuskan manusia memiliki sepak terjang dalam mencapai suatu tujuan. Namun, tetap berpegang pada rel atau pedoman sehingga tidak tersesat dan tidak menghalalkan segala cara dalam mencapai tujuan yang dimaksud.

Jika dilihat dari filosofi kelima wanda yang menggambarkan kehidupan manusia, Tari Topeng Klana berada pada puncaknya. Tari Topeng Klana menggambarkan manusia dengan segala pola pikir, fisik, dan psikologi yang matang. Sehingga jika dilihat dari segi penamaan, Klana ditulis tanpa huruf ' $\mathrm{e}$ ' yang merupakan akronim dari kata kalae ana atau ketika ada. Maksud dari ketika ada adalah ketika manusia serba ada dan serba mempunyai kemapanan. Seperti mapan dalam pola pikir, tenaga, bahkan harta. Sehingga dalam mencapai tujuan manusia mengerahkan seluruh apa yang dimilikinya namun tetap berpegang pada pedoman. Kata Klana sendiri sering dipadankan dengan kelana atau mengadakan suatu perjalanan atau mengembara. Sosok Klana juga digambarkan kegigihan seseorang dalam mencapai suatu tujuan. Segala sesuatunya dikerahkan bahwa dalam mengejar suatu cita-cita manusia hendaknya memiliki semangat dan power yang kuat agar tidak sirna terkikis oleh kemajuan zaman.

Gerak yang semangat dan penuh energi dalam Tari Topeng Klana sering diinterpretasikan dengan sifat angkara murka, nafsu dan ngumbar kepuasan atau mengumbar kepuasan dengan adanya gerak seperti tertawa terbahak-bahak. Namun, jika ditilik lebih dalam, maksud dari keangkaraan, nafsu dan ngumbar kepuasan adalah layaknya manusia normal yang penuh ketidakpuasan. Kadangkala dalam mencapai suatu tujuan menemukan ketidakpuasan terhadap hasil yang dicapai sehingga perlu meningkatkan usaha agar hasil yang didapatkan lebih maksimal.

\section{Interpretasi Masyarakat Terhadap Makna Simbolik Tari Topeng Klana Cirebon gaya Palimanan}

Masyarakat Cirebon memiliki watak yang keras atau atos kaya watu cadas dalam hal batin yang tak tergoyahkan. Watak yang keras tersimbol dalam arsitektur Goa Sunyaragi yang merupakan tumpukan batu cadas yang keras (Noer, 2016, https://www.lyceum.id/menusacerbon-siapa-dia/, 31 Agustus 2016). Watak tersebut terepresentasi dalam gerak Tari Topeng Klana memiliki gerak staccato atau patah-patah yang membuat Tari Topeng Klana memiliki perhatian lebih di masyarakat (wawancara dengan Wiyono, 5 Februari 2019). Relevansi antara gerak dengan watak masyarakat Cirebon, membuat Tari Topeng Klana memiliki posisi yang khusus di hati masyarakat Cirebon.

Konotasi positif yang didasarkan pada pandangan-pandangan seniman terhadap Tari Topeng Klana tidak berjalan beriringan dengan pandangan penonton. Pandangan penonton atau masyarakat terhadap makna Tari Topeng Klana lebih kepada konotasi negatif, sehingga hal ini menjadi suatu kontradiktif atau berlawanan. Masyarakat lebih menilai Tari Topeng Klana sebagai tarian yang menggambarkan angkara murka dan manusia yang tidak bisa mengontrol hawa nafsu duniawi dengan alasan gerak yang sigrak atau enerjik disertai dengan penggunaan topeng yang garang seperti seseorang yang sedang marah. Pandangan masyarakat yang bertentangan dengan makna yang dituturkan oleh seniman justru seolah menjadi suatu kebenaran atau bersifat paradoksal dan konotasi positif yang dituturkan seniman seolah tidak ada keberadaannya di masyarakat. Namun, ada masyarakat yang ketika peneliti wawancarai dengan memberikan konotasi yang positif tetapi tidak memberikan alasannya secara detail.

Interpretasi masyarakat yang seolah bertentangan dengan pendapat seniman menimbulkan suatu peryataan bahwa seniman gagal dalam mengomunikasikan makna simbol dalam Tari Topeng Klana. Namun, 
masyarakat yang memberikan makna bertentangan dengan seniman merupakan suatu hal yang wajar mengingat simbol-simbol dalam tari yang dalam pemaknaannya tidak harus sama atau tidak harus menimbulkan reaksi yang sama atau disebut significant symbol dan bukan merupakan simbol alami atau natural sign yang menimbulkan reaksi yang sama bagi setiap orang (Jazuli 2014: 123).

Berdasarkan pendapat-pendapat masyarakat dan hasil penelitian, masyarakat yang memberikan interpretasi yang berbeda dengan seniman setidaknya ada beberapa faktor dan alasan yang melatarbelakangi perbedaan interpretasi dalam Tari Topeng Klana Cirebon antara lain.

Pertama, Ketidaktahuan masyarakat yang menimbulkan interpretasi yang seolah bertentangan. Ketidaktahuan tersebut dapat timbul akibat jarangnya menonton pertunjukan. Hal ini dibuktikan dengan adanya masyarakat yang memberikan makna positif terhadap Tari Topeng Klana Cirebon yang ternyata sering melihat pertunjukan walau dalam bentuk latihan.

Kedua, penghayatan yang kurang mendalam bagi penonton yang hanya menonton saja. Terdapat masyarakat yang ketika peneliti melakukan wawancara menjawab dengan "mbuh ya bli weruh da kita mah ngan nongton biasa kah" (tidak tahu karena saya hanya menonton biasa). Sehingga masyarakat merasa tidak memiliki suatu tugas untuk menerjemahkan pertunjukan yang dilihatnya dengan penghayatan yang mendalam. Sehingga masyarakat kembali dengan suatu kebiasaan yang selalu melihat sesuatu hanya dari segi visual atau yang nampak oleh mata tanpa meresapi atau menghayati lebih dalam terhadap apa yang dilihatnya. Seperti dalam Tari Topeng Klana dengan gerakan yang enerjik maka dikonotasikan dengan sikap yang penuh amarah.

Ketiga, referensi masyarakat dalam menginterpretasikan sesuatu berdasarkan pengalaman dan pengetahuan yang populer di lingkungannya. Seperti Tari Topeng Klana yang diinterpretasikan masyarakat sebagai sosok Rahwana atau Dasamuka dalam cerita Ramayana karena kemiripan karakter dalam gerak dan bentuk topeng yang menyeramkan sehingga memaknai Tari Topeng Klana dengan sosok Rahwana yang penuh amarah dan watak yang negatif. Padahal berdasarkan penuturan narasumber sebenarnya Klana bukanlah sosok Rahwana dalam cerita Ramayana melainkan Klana adalah Klana Menakjingga dalam cerita Panji. Namun, di Cirebon cerita Panji seolah kurang begitu populer di telinga masyarakat karena mungkin awal perkembangan cerita panji berawal dari Jawa Timur. Seniman melihat lakon dalam Tari Topeng Klana dengan melihat karakternya dari sudut yang berbeda. Seniman memandang tokoh Klana sebagai seseorang atau manusia yang bercita-cita tinggi dengan idealisme yang estetis (Wardhana dalam Supriyanto: 2012: 3). Sama dengan Tari Topeng Klana Cirebon yang dikonotasikan oleh seniman sebagai manusia yang memiliki cita-cita atau tujuan hidup dengan semangat untuk mencapainya dengan suatu keidealismeannya atau pedoman-pedoman untuk mencapai tujuan tersebut.

Keempat, faktor seniman juga berpengaruh dalam interpretasi makna yang bertentangan dalam Tari Topeng Klana Cirebon. "Garep weruh garep beli artie sing nonton mah sing penting kita joged maknae mengkenen, maknae sepak terjange manusia dalam mencapai tujuan" (mau tahu atau tidak itu terserah penonton, yang penting kita menari maknanya begini, maknanya sepak terjang manusia dalam mencapai tujuan) begitulah ungkapan Sukarta ketika Peneliti kala itu bertanya mengapa Tari Topeng Klana yang geraknya seolah tidak sopan tapi malah digunakan untuk menyambut presiden. Berdasarkan penuturan narasumber dapat ditarik suatu simpulan bahwa dari sudut seniman pun seolah tidak adanya beban atau keharusan bahwa makna dalam Tari Topeng Klana Cirebon yang diterjemahkan penonton itu sesuai dengan yang dikehendaki seniman. Seniman hanya berpikir menari dan menari saja dan justru seolah membebaskan penonton dalam menerjemahkan.

\section{SIMPULAN}

Tari Topeng Klana Cirebon gaya Palimanan mengundang pemaknaan yang berbeda bagi setiap orang yang melihatnya. Perbedaan pemaknaan suatu tari merupakan sesuatu hal yang wajar, mengingat simbol dalam tari adalah significant simbol. Begitu pula dengan Tari Topeng Klana Cirebon gaya Palimanan yang memiliki dua pemaknaan yang merupakan pendapat dari masyarakat dan seniman. Masyarakat sebagai penonton 
memaknai Tari Topeng Klana Cirebon gaya Palimanan sebagai gambaran manusia yang penuh dengan angkara murka, tidak bisa mengendalikan hawa nafsu dan penuh dengan tabiat buruk yang didasarkan pada gerak enerjik, kasar, penuh arogansi dan bentuk ekspresi topeng yang terkesan menyeramkan layaknya orang yang sedang marah. Namun, seniman memandang gerak yang enerjik sebagai gambaran semangat manusia dalam mencapai tujuan hidup serta apabila dilihat dari urutan penampilan, Tari Topeng Klana merupakan puncak dari kelima wanda yang menjadi simbol manusia yang berada pada puncak kematangan baik fisik maupun psikis dan kemapanan dalam hal berpikir, kemapanan harta dan segala sesuatu yang dimiliki, sehingga dalam mencapai tujuan manusia mengerahkan apa yang dimiliki dengan berpegang teguh pada pedoman.

Interpretasi masyarakat yang seolah bertentangan dengan pandangan dan maksud seniman setidaknya dipengaruhi oleh empat faktor antara lain 1) Ketidaktahuan masyarakat, 2) Penghayatan yang kurang mendalam, 3) Referensi masyarakat dalam menginterpretasi berdasarkan pengalaman dan pengetahuan yang populer di lingkungannya, serta 4) Faktor seniman.

Berdasarkan hasil penelitian, makna Tari Topeng Klana nampaknya akan tetap memiliki dua interpretasi yang bertentangan antara pendapat penonton dengan pendapat seniman. Hal itu dikarenakan seniman seperti tidak merasa memiliki tugas dalam menyosialisasikan makna yang sebenarnya ingin disampaikan kepada penonton. Seniman hanya berorientasi kepada Tari Topeng Klana sebagai hiburan semata.

\section{DAFTAR PUSTAKA}

Ardin. 2017. "Makna Simbolik Pertunjukan Linda dalam Upacara Karia di Kabupaten Muna Barat Sulawesi Tenggara". Catharsis. 6(1), 57-64.

Ariyiliyanto, Algon. 2013. "Motivasi Kerja: Studi Indigenous pada Guru Bersuku Jawa di Jawa Tengah". Journal Of Social and Industrial Psychology. 2(2), 1-13.

Berger, Arthur Asa. 2005. Tanda-Tanda dalam Kebudayaan Kontemporer, Suatu Pengantar Semiotika. Terjemahan M. Dwi Marianto dan Sunarto. Yogyakarta: Tiara Wacana Yogya.
Cahyono, Agus. 2006. "Seni Pertunjukan Arak-Arakan dalam Upacara Tradisional Dugdheran di Kota Semarang". Harmonia. 7(3), 67-77.

Dyah, Ayoeningsih. 2007. "Makna Simbolis pada Unsur Visual Kostum Tari Topeng Babakan Cirebon Keni Arja di Desa Slangit". ITB Jurnal Visual Art. 1(2), 224245.

Endraswara, S. 2003. Mistik Kejawen: Sinkretisme, Simbolisme, dan Sufisme dalam Budaya Spiritual Jawa. Jogjakarta: Narasi.

Handayani, Tri. 2017. "Makna Simbolik Tari Lengger Solasih di Sanggar Satria Wonosobo". Jurnal Seni Tari. 6(1), 1-8.

Hartono dan Wahyu Lestari. 2002. "Nilai Budi Pekerti dalam Tari Tradisional Klasik Gaya Yogyakarta”. Harmonia. 3(2): $1-10$.

Jaeni. 2014. Kajian Seni Perunjukan dalam Perspektif Komunikasi Seni. Bogor: IPB Press.

Jazuli. 2014. Sosiologi Seni: Pengantar dan Model Studi Seni Edisi 2. Yogyakarta: Graha Ilmu.

Jazuli. 2016. Peta Dunia Seni Tari. Sukoharjo: CV Farishma Indonesia.

Kusmayati, Hermien. 2000. Arak-arakan Seni pertunjukan dalam Upacara Tradisional di Madura. Yogyakarta: Tarawang Press.

Masunah, Juju dan Uus Karwati. 2003. Topeng Cirebon. Bandung: P4ST UPI.

Noer, Nurdin M. (31 Agustus 2016) Online. https://www.lyceum.id/menusa-cerbonsiapa-dia/ (diakses pada 29 Juli 2019).

Parmono, Kartini. 1995. "Simbolisme Batik Tradisional". Filsafat. Seri 23 November 1995: 28-35

Sachari, Agus. 2002. Estetika Makna, Simbol dan Daya. Bandung: Penerbit ITB.

Suanda, Toto Amsar. 2009. Tari Topeng Panji Cirebon Suatu Kajian Simbolis. Tesis. Institut Seni Indonesia Yogyakarta.

Sugiyono. 2015. Metode Penelitian Pendidikan Pendekatan Kuantitatif, Kualitatif, dan R\&D. Bandung: Alfabeta.

Suherman. 2016. "Patung Tau-Tau di Toraja Provinsi Sulawesi Selatan: Kajian Simbol Susanne K. Langer". Imaji. 14(2), 1-19.

Supriyanto. 2012. "Tari Klana Alus Sri Suwela Gaya Yogyakarta Perspektif Joged Mataram". Joged. Volume 3 Nomor 1: 116. 